\title{
Massive ear keloids: Natural history, evaluation of risk factors and recommendation for preventive measures - A
} retrospective case series [version 1; peer review: 2 approved with reservations]

\author{
Michael Tirgan
}

Keloid Research Foundation, New York, NY, 10023, USA

\author{
V1 First published: 13 Oct 2016, 5:2517 \\ https://doi.org/10.12688/f1000research.9504.1 \\ Latest published: 21 Mar 2017, 5:2517 \\ https://doi.org/10.12688/f1000research.9504.2
}

\section{Abstract}

Keloid disorder (KD) is an inherited wound healing ailment, frequently seen among Africans /African Americans and Asians. Genetics of this disorder continues to be obscure and poorly understood. Clinical manifestation of KD is quite variable and very diverse, spanning from individuals with one or very few small keloidal lesions, to those with numerous and very large lesions covering large portion of their skin. Ears are common locations for development of keloids. Ear piercing is by far the leading triggering factor for ear keloid formation in genetically predisposed individuals. Although there are numerous publications about ear and earlobe keloids, there is a void in medical literature about massive ear keloids. This paper focuses on the natural history of massive ear keloids and risk factors that lead to formation of these life-changing and debilitating tumors and recommendations for prevention.

Keywords

Ear Keloid , Cryotherapy

\section{Open Peer Review}

\begin{tabular}{lccc} 
Approval Status & $? \checkmark ?$ \\
& 1 & 2 & 3 \\
\hline version 2 & $?$ & & $?$ \\
(revision) & view & view & view \\
21 Mar 2017 & 4 & 4 & \\
& $?$ & $?$ & \\
version 1 & $?$ & view & \\
13 Oct 2016 & view &
\end{tabular}

1. Robert Sidbury, University of Washington School of Medicine, Seattle, USA

2. Amy J. McMichael, Wake Forest School of Medicine, Winston-Salem, USA

\section{Mohamed Badawy Hassan Tawfik Abdel-}

Naser, Ain Shams University, Cairo, Egypt Any reports and responses or comments on the article can be found at the end of the article. 
Corresponding author: Michael Tirgan (htirgan@gmail.com)

Competing interests: No competing interests were disclosed.

Grant information: The author declares that no grants were involved in supporting this work.

Copyright: $₫ 2016$ Tirgan M. This is an open access article distributed under the terms of the Creative Commons Attribution License, which permits unrestricted use, distribution, and reproduction in any medium, provided the original work is properly cited.

How to cite this article: Tirgan M. Massive ear keloids: Natural history, evaluation of risk factors and recommendation for preventive measures - A retrospective case series [version 1; peer review: 2 approved with reservations] F1000Research 2016, 5 :2517 https://doi.org/10.12688/f1000research.9504.1

First published: 13 Oct 2016, 5:2517 https://doi.org/10.12688/f1000research.9504.1 


\section{Introduction}

Patients with keloid disorder (KD) carry a genetic abnormality that predisposes them to the disorder ${ }^{1}$. Although no convincing genetic abnormalities have been linked to $\mathrm{KD}$, clinical observation suggests that the genetic predisposition to KD has a broad spectrum $^{2}$. Individuals who suffer from mild form of the disorder typically develop one or few slow-growing keloidal lesions, whereas individuals with the severe form of the disorder often develop several large keloids. In addition to the genetics, other factors also play important roles in clinical presentation of KD. Most importantly, there must exist an injury to the skin that would trigger abnormal wound healing response that leads to the formation of keloid lesions ${ }^{2}$. Figure 1 depicts a young African American male who developed an earlobe keloid following the piercing of his right ear. In addition, he also sustained several sharp and deep injuries to his neck, left shoulder and left arm. All wounded areas subsequently transformed into linear keloids. Therefore, it is safe to conclude that had he not pierced his ear or sustained other injuries, he would not have developed any of these keloids and would have remained completely asymptomatic. Therefore, simple clinical observations of this one patient teaches us that certain individuals harbor the KD genetic abnormality yet remain asymptomatic only because they have not pierced their ears or sustained a serious injury to their skin.

Another important fact about $\mathrm{KD}$, which is well exemplified in this case, is that adjacent and even distant skin are also affected by the keloidal process; thus, the wounding of normal-appearing skin will inevitably lead to the formation of new keloid lesions.
In addition to genetics and skin injuries, the third important factor in the clinical presentation of KD is the age of the individual. The peak age of onset of KD occurs during puberty; however, certain types of skin injuries only occur later in life. For instance, the typical age of those undergoing cardiac bypass surgery or facelift surgery is in 6th and 7th decade of life. As such, certain KD carriers will remain asymptomatic until they undergo their first surgery and end up with chest-wall or peri-auricular keloids ${ }^{1,3}$. Race, gender, passage of time and therapeutic interventions are other important factors that play their own unique role in clinical presentation of this disorder. The wide spectrum of these factors contributes to highly variable phenotype of $\mathrm{KD}$. The clinical presentation of $\mathrm{KD}$ is to some extent race and gender dependent. Large and tumoral keloids, including massive ear lesions, are more often encountered among Africans, African Americans and individuals with black skin².

Focusing our attention to the ears, it is common knowledge that keloid lesions grow over time. With medical interventions, some KD lesions respond well to the treatments, but some lesions fail to respond, or even get worse and grow much larger. By far, the most important factor in development of all primary keloidal lesions is the initial wounding injury of the skin. However, the surgical removal of ear keloids that is commonly performed by ENT specialists, plastic surgeons and general dermatologists, defies this very basic principal of keloid formation. The extent of the injury to the surrounding skin when an ear keloid is surgically removed is obviously several fold greater than the primary injury sustained from the piercing procedure. This iatrogenic injury will undoubtedly trigger a keloidal wound healing response that is not only more
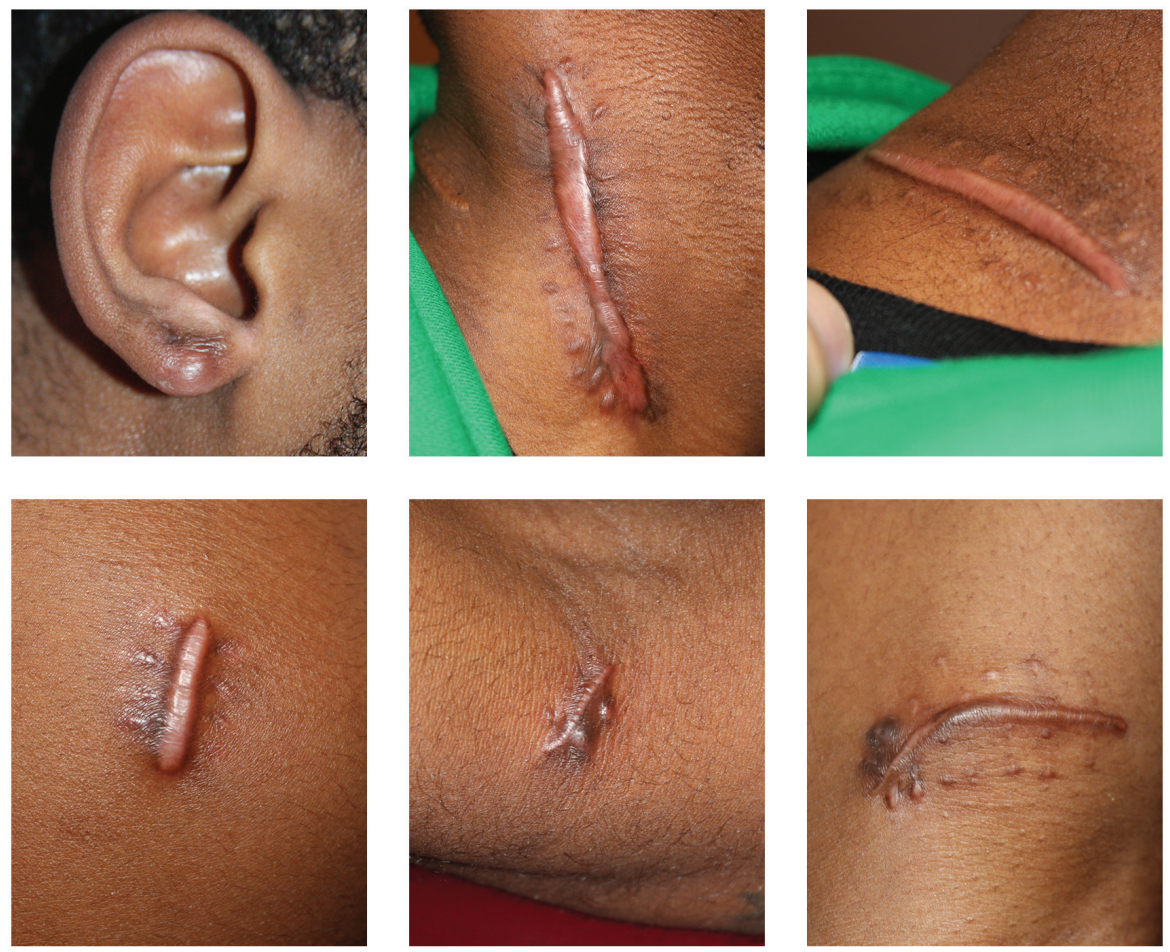

Figure 1. Young African American male with several keloidal skin lesions on various parts of his skin. Notice that each wounded area of skin has transformed into a keloidal lesion. 
intense than the one triggered by the original piercing event but also much greater in magnitude and distribution. Studies have indicated that almost all ear keloids and almost all other keloid lesions will relapse after surgery; hence, the need for adjuvant treatment has been emphasized by almost every author who has published on this topic. Adjuvant treatments in the form of post-operative steroid injections ${ }^{4}$, pressure devices ${ }^{5}$ or even radiation therapy ${ }^{6}$ are often incorporated in management of ear keloids in order to counteract the fully expected keloid recurrence after surgery. However, despite the meticulous use of all available adjuvant treatments, a large number of patients will suffer from recurrent ear keloids and undergo second, third or fourth surgeries. Unfortunately, the ear keloids will continue to relapse in many instances. At some point, the surgeon, the patient, or even both will abandon therapeutic interventions.

This article focuses on these unfortunate cases; instances of recurrent large, semi-massive, and massive ear keloids among mostly young patients who ultimately accept the reality that surgery and/or adjuvant radiation therapy cannot treat their keloids, thereby resigning themselves to living with huge tumoral keloids hanging from their ears, an unwanted and unpleasant outcome that impacts every aspect of their daily lives.

\section{Materials and methods}

This is a retrospective analysis of 283 consecutive patients with ear keloids who were seen by the author in his keloid specialty medical practice. Patients with post-otoplasty ear keloids, and those with post-facelift peri-auricular keloids were not included in this study. The underlying research project for this retrospective study was determined by the Western IRB to meet the conditions for exemption under 45 CFR 46.101(b)(4). Consent is not required for studies that are determined to be exempt under 45 CFR 46.101(b)(4).

Keloids were assessed visually and categorized according to their size into four separate groups. Other than author's recently published keloid staging system ${ }^{7}$, there are no other previously described methodologies that would allow for more precise grouping of the ear keloids.

Table 1 summarizes characteristics of the patients within each group.

1- Massive ear keloids: the size of the keloid mass is greater than the surface area of the corresponding ear. Thirteen patients $(4.5 \%)$ met this criterion. Three patient were Caucasians, and 10 were African Americans. Four patients (three females and one male) had bilateral massive ear keloids. Figure 2 depicts several patients in this category.

2- Semi-massive ear keloids: the size keloid mass is at least $50 \%$ of the surface area of the corresponding ear. Eighteen patients $(6.3 \%)$ met this criterion. Two patients were Caucasians, and sixteen were African Americans. Figure 3 depicts several patients in this category.
3- Large ear keloids: the size of the keloid mass was more than the size of the corresponding earlobe. In total, 181 patients met this criterion. Forty-nine patients were Caucasians or Asians, and 132 patients were African Americans. Figure 4 depicts several patients in this category.

4- Small ear keloids: the size of the keloid mass is less than the size of the corresponding earlobe. Seventy-one patients met this criterion. Twenty-eight patients were Caucasians or Asians, and 43 patients were African Americans. Figure 5 depicts several patients in this category.

Table 1. Patient characteristics.

\begin{tabular}{|l|c|}
\hline Patients N= & $\mathbf{2 8 3}$ \\
\hline Asians/Caucasians & $\mathbf{8 2}$ \\
\hline Male & 30 \\
\hline Female & 52 \\
\hline African Americans & $\mathbf{2 0 1}$ \\
\hline Male & 79 \\
\hline Female & 122 \\
\hline Massive ear keloids & $\mathbf{1 3}$ \\
\hline $\begin{array}{l}\text { Gender } \\
\text { Male }\end{array}$ & 6 \\
\hline Female & 7 \\
\hline $\begin{array}{l}\text { Race } \\
\text { Caucasian - Asian }\end{array}$ & 3 \\
\hline African American & 10 \\
\hline Semi-massive ear keloids & $\mathbf{1 8}$ \\
\hline $\begin{array}{l}\text { Gender } \\
\text { Male }\end{array}$ & 6 \\
\hline Female & 12 \\
\hline Race \\
\hline Caucasian - Asian & 25 \\
\hline African American & 109 \\
\hline Large ear keloids & 16 \\
\hline $\begin{array}{l}\text { Gender } \\
\text { Male }\end{array}$ \\
\hline Female \\
\hline Race \\
\hline African American \\
\hline Small ear keloids
\end{tabular}



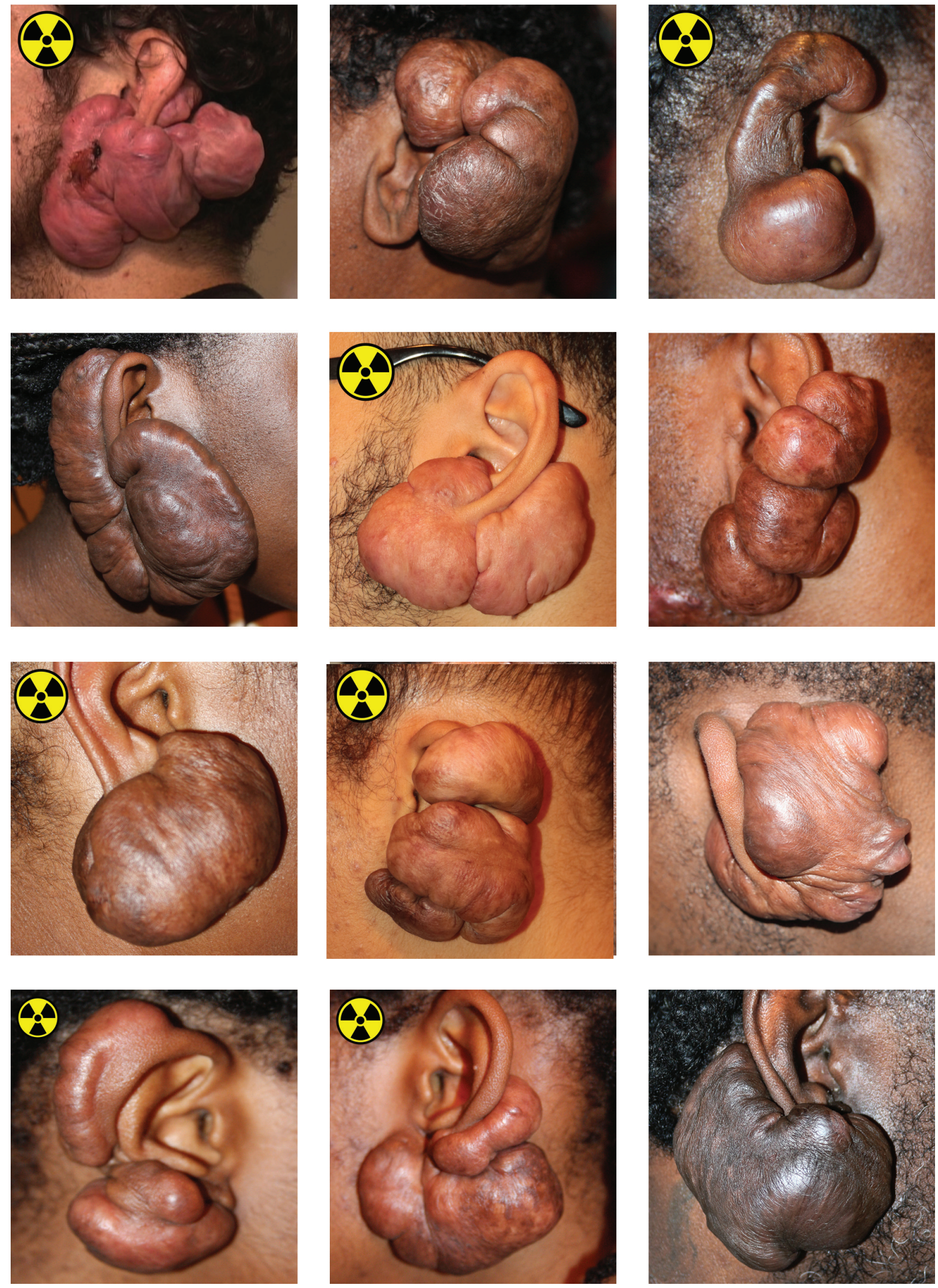

Figure 2. Massive ear keloids are larger than the size of corresponding ear. Yellow radiation signs identify patients who have previously received adjuvant radiation therapy after removal of their ear keloids. 

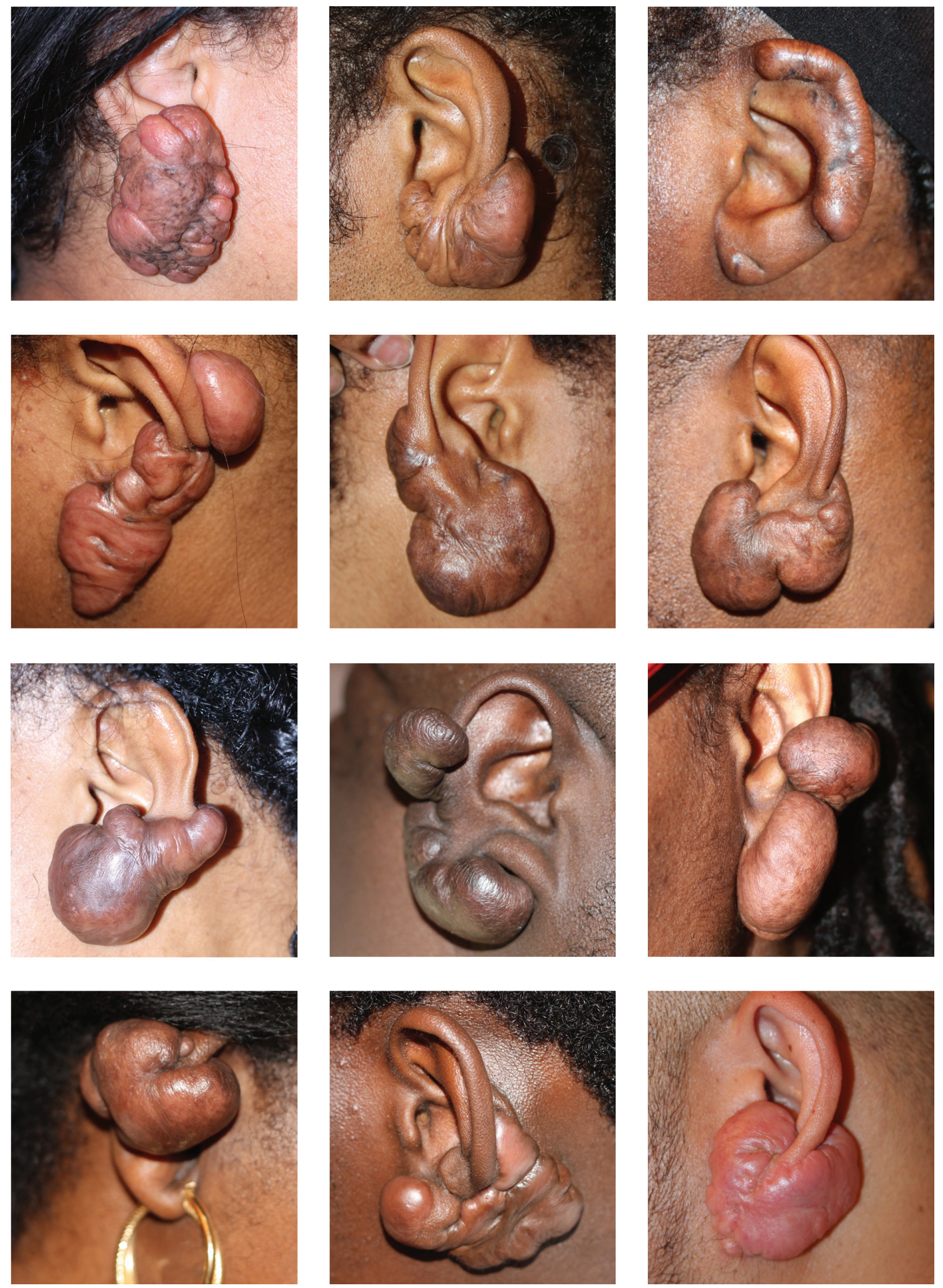

Figure 3. Semi-massive ear keloids measure at least half the size of the corresponding ear. 

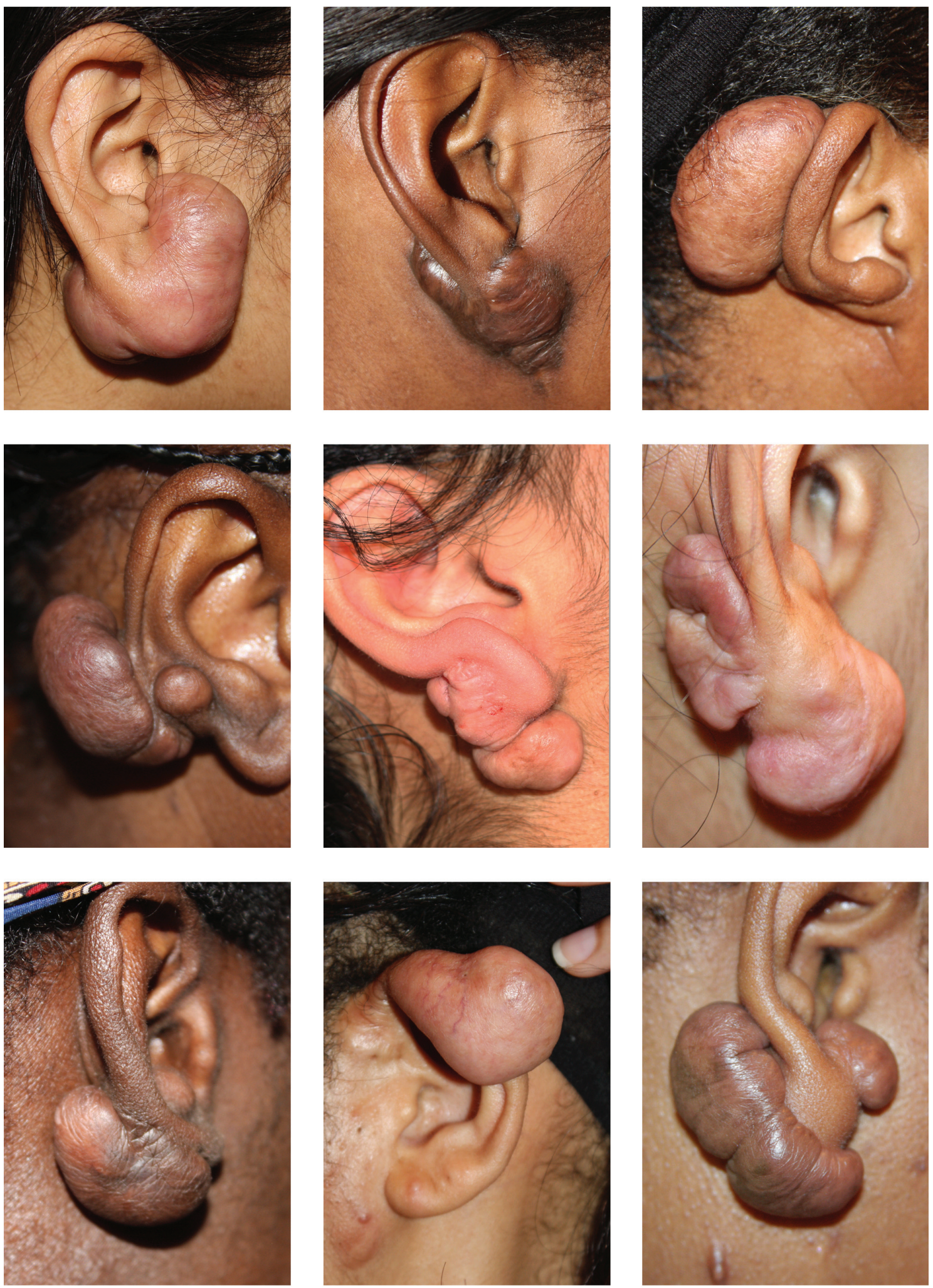

Figure 4. Large ear keloids measure larger than the corresponding earlobe. 

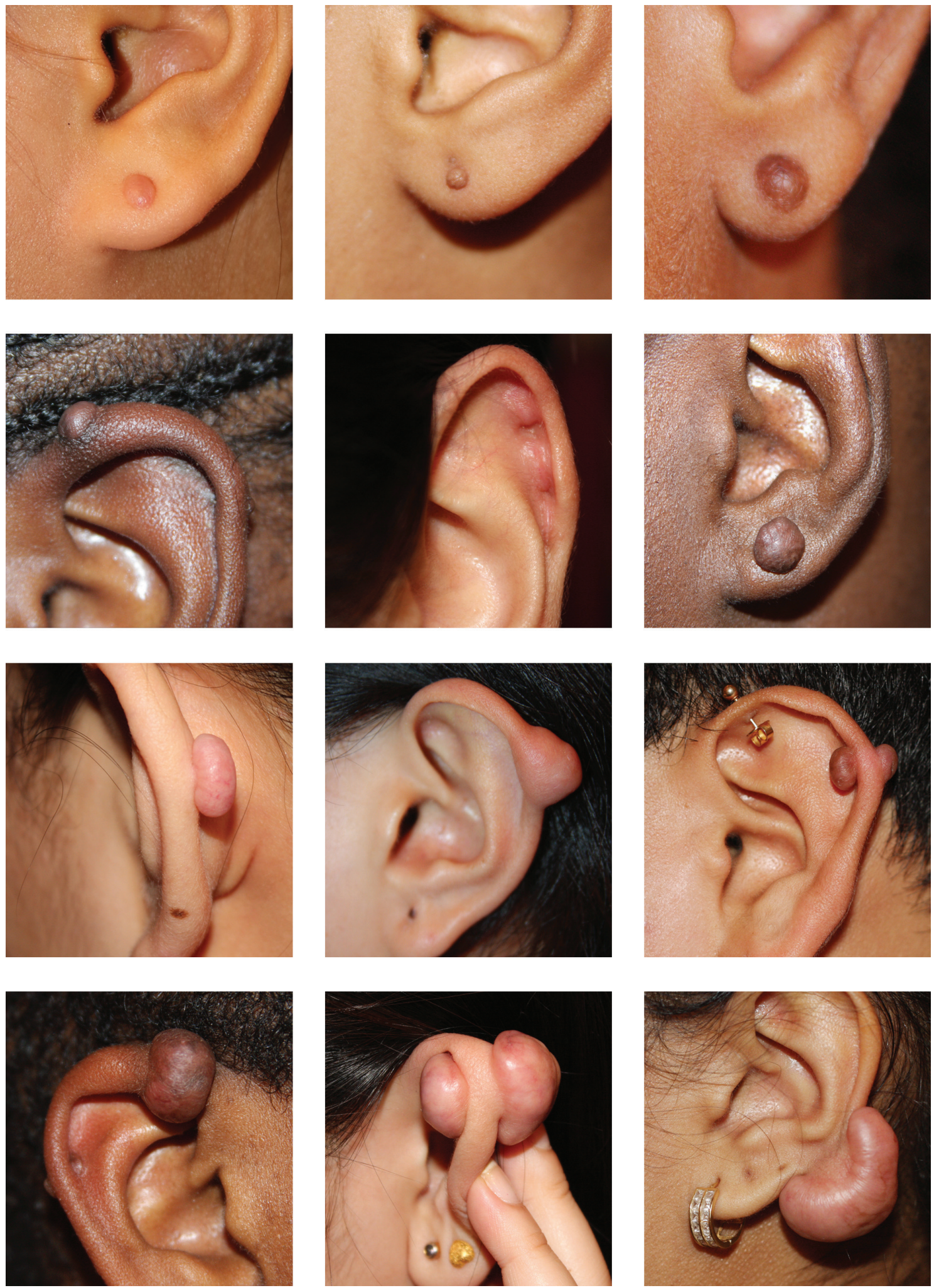

Figure 5. Early stage, primary ear keloids in various stages of development. 
Table 2 shows the stage classification of solitary ear keloids according to the author's new Keloid Staging System ${ }^{6}$.

\section{Results}

Although this study is limited by its size, and patients were drawn from only one medical practice that does not offer surgery for treatment of keloids, several interesting factors stand out as risk factors for development of large, semi-massive and massive ear keloids. More females were noted among each study group. However, the gender may be simply related to the fact that more women pierce their ears.

$\square$ African/African American race was noted to be a major potential risk factor in all four groups, most importantly among those with massive, semi-massive ear keloids, with only five Caucasians/Asians among the 31 patients in both these groups.

$\square$ Prior keloid removal surgery was the most important risk factor among all patients with massive and semi-massive ear keloids. Without exception, all these patients had undergone anywhere between one to seven prior keloid removal surgeries.

$\square$ Prior keloid removal surgery was the most important risk factor among patients with large ear keloids. One hundred thirty-one patients $(73 \%)$ had a history of prior keloid removal surgery.

The patients' history of prior keloid removal surgery is summarized in Table 3.

\section{Discussion}

Surgery is a commonly practiced therapeutic intervention for removal of ear keloids. Based on the findings of this study, the author proposes the following designations for keloid lesions.

\section{Primary ear keloids}

A primary ear keloid is a keloid that has not been previously treated with surgery. Keloid lesions can form in any part of the ear; however, the location of the keloid solely depends on the site of the prior injury or ear piercing. All primary ear keloids start as a small skin lesion and grow over time. The longer a keloid is present, the larger it will become. Figure 5 depicts several examples of primary keloids in various stages of development.

\section{Secondary ear keloids}

A secondary ear keloid is a new keloid that forms at the site of surgery for the removal of a primary keloid. Figure 2, Figure 3, and Figure 4 depict numerous cases of secondary ear keloids.

It is undisputable that the extent of the injury from the surgical removal of a primary ear keloid is significantly greater than the injury sustained from ear piercing. It is also logical to conclude that the extent of skin injury has a direct and linear relationship with the size and mass of keloid lesions. These two simple facts explain why keloid removal surgery can trigger development of larger keloids. Cognizant of the fact that there are patients whose keloids do not recur after surgery, we must be well aware, and acknowledge the deleterious effects of surgery, and the nightmare that is imposed on patients who end up developing large, semi-massive or massive ear keloids. The psychological stress and anxiety that is imposed on a young person by having to live with a worsened ear keloid is very real and life changing 8 .

Indiscriminate and repeated surgical attempts to remove ear keloids are also associated with disfigurement of the ear. By attempting to remove the entire keloid, surgeons remove part of the earlobe or performs a wedge resection and remove some of the ear cartilage and soft tissue adjacent to the keloid. Even if this approach does not lead to the recurrence of the keloid, which it often does, it will result in the loss of normal ear anatomy and a poor

Table 2. Stage grouping for patients with solitary ear keloids.

\begin{tabular}{|l|l|l|}
\hline Massive ear keloid & Stage 1C & $\begin{array}{l}\text { Presence of only one keloidal lesion that measures } \\
\text { greater than } 10 \text { centimeters in any dimension. }\end{array}$ \\
\hline $\begin{array}{l}\text { Large and Semi-massive } \\
\text { ear keloids }\end{array}$ & Stage 1B & $\begin{array}{l}\text { Presence of only one keloidal lesion that measures } \\
2.1-10 \text { centimeters in any dimension. }\end{array}$ \\
\hline Small ear keloids & Stage 1A & $\begin{array}{l}\text { Presence of only one keloidal lesion that measures } \\
\text { no greater than 2 centimeters in any dimension. }\end{array}$ \\
\hline
\end{tabular}

Table 3. History of prior ear keloid removal surgery.

\begin{tabular}{|l|l|l|}
\hline & $\begin{array}{l}\text { Number of } \\
\text { patients }\end{array}$ & $\begin{array}{l}\text { Number of patients } \\
\text { with prior ear keloid } \\
\text { removal surgery }\end{array}$ \\
\hline Massive ear keloid & 13 & $13(100 \%)$ \\
\hline $\begin{array}{l}\text { Semi-massive ear } \\
\text { keloids }\end{array}$ & 18 & $18(100 \%)$ \\
\hline Large ear keloids & 181 & $131(73 \%)$ \\
\hline
\end{tabular}



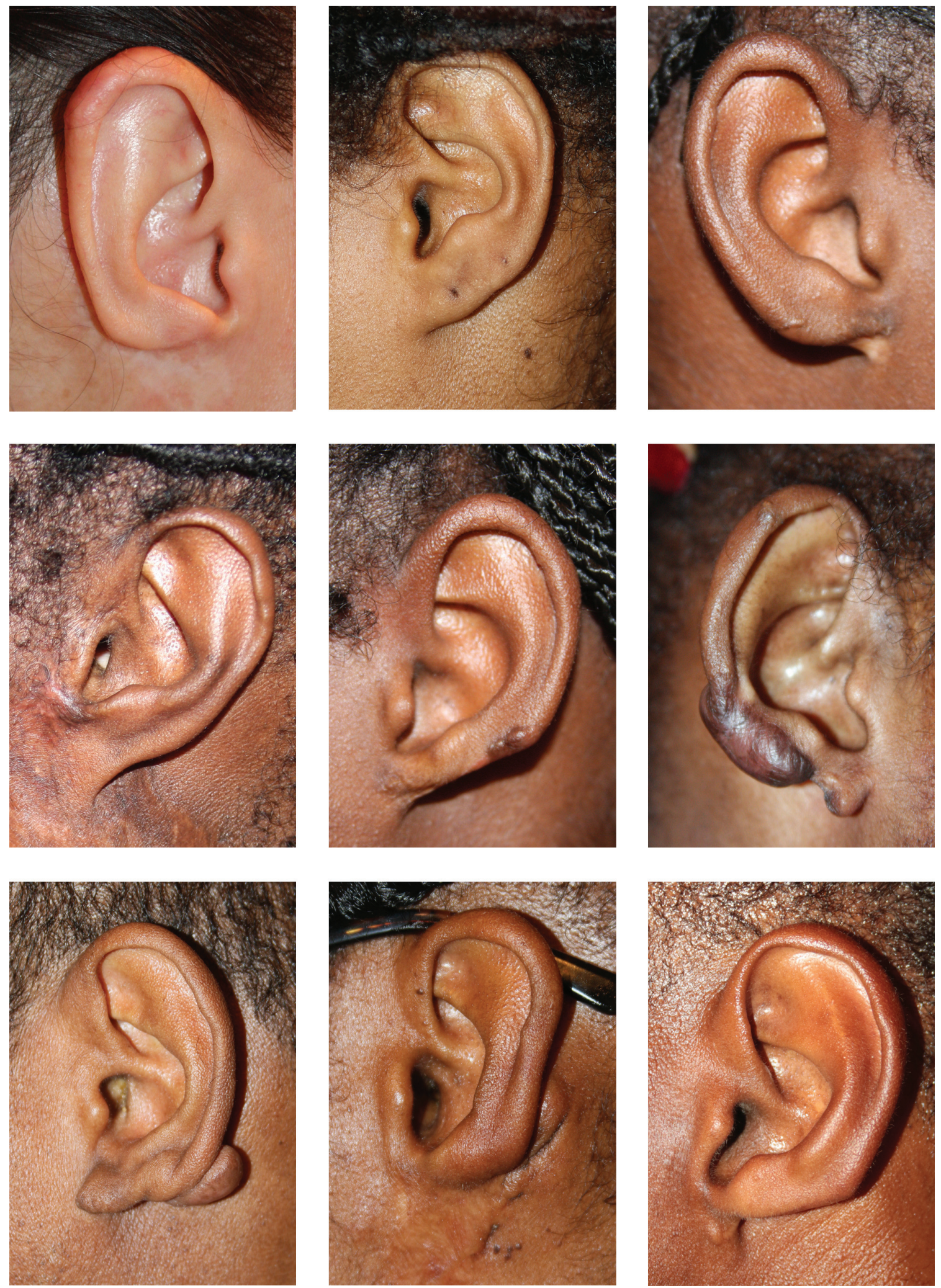

Figure 6. Poor surgical outcomes for which the true incidence remains unreported. Notice the disfiguration of normal ear anatomy and the loss of ear tissue from prior surgeries. 
aesthetic outcome. Figure 6 depicts several examples of such poor outcomes. A very common shortcoming of several publications on the surgical treatment of ear keloids ${ }^{2-4}$ is lack of reporting of the aesthetic outcomes.

Recently advocated approach of surgery in combination with adjuvant radiation therapy ${ }^{6}$, although it may yield to a lower keloid recurrence rate, it exposes all patients to potentially grave adverse effects of radiation therapy. Those of us who take on the task of treating keloid patients, often teenagers and young adults, need to be very cognizant about the risks associated with the treatments that we offer to our patients. Although surgery provides a quick-fix solution to an ear keloid, exposing children and young adults to a procedure that has even $1 \%$ risk of causing massive or semi-massive ear keloid is unacceptable, let alone a $10.8 \%$ risk that is observed among 283 consecutive cases presented here. It is unfortunate that the data on incidence of massive or semimassive ear keloids has never been published, but a rate of greater than $10 \%$ among author's patients is very disturbing and resonates like a loud siren calling for more careful analysis of outcome data of all surgical interventions.

Furthermore, the carcinogenic risk of radiation therapy is real and should not be under-estimated. Exposing teenagers and young adults to such a treatment, even with a small long term risk, is simply unacceptable. We need to bear in mind that we are not treating elderly cancer patients with radiation; we are treating teenagers and young adults. No matter how well the ear tissue is isolated and shielded, many thousands of hematopoietic stem cells that circulate in the capillaries and venules of the ear tissue will be exposed to ionizing irradiation. The author doubts that even one radiation therapist will be willing to expose his or her own ear tissue or that of his or her child to the radiation that is so casually offered to many young adults with KD.

Moreover, the real rate of keloid non-recurrence after adjuvant radiation therapy remains unknown. Most studies report their outcome after a short interval of few months to two years. A recent comprehensive review of adjuvant radiation therapy ${ }^{9}$ for treatment of keloid lesions screened 207 publications, many of which were excluded for not describing a minimum follow up. The authors limited their study to 33 articles with only 10 studies providing incidence of recurrence. The mean time to recurrence was $14.8 \pm 6.7$ months with a range of 2-36 months post-treatment. True long term recurrence rate of keloids after adjuvant radiation therapy remains unknown. Author is currently treating a patient with massive left ear keloid who had her first recurrence 13 years after receiving adjuvant radiation therapy. Figure 2 depicts several cases of massive ear keloids in patients who had previously received adjuvant radiation therapy after surgical removal of their ear keloids.

\section{Need for a paradigm shift in treating primary ear keloids}

The successful treatment of human diseases is reliant on thorough understanding of the underlying processes that lead to the development of particular illnesses. The basic principal of treating keloidal lesions is the destruction of the abnormal tissue with a method that will not trigger the underlying keloidal wound healing response. Surgical removal of keloids will indeed trigger this pathological wound healing response and can result in development of a much larger ear keloids. Figures 8 depicts the vicious cycle of surgery that can results in formation of semimassive and massive ear keloids; a cycle that all 31 patients in this study, and all those shown in Figure 2 and Figure 3 have been through. The development of all secondary keloids can be effectively prevented if we simply stop performing surgery on keloid patients all together. In the author's opinion, supported by his own experience, the paradigm shifting treatment approach is a move to utilize contact cryotherapy for treatment of all primary ear keloids. Furthermore, the author believes that proper application of cryotherapy can effectively remove all primary ear keloids and prevent development of all secondary keloids. Results with high therapeutic success rate have been previously reported by others $^{10-13}$. Figure 7 depicts several examples of durable results achieved by author for patients with primary ear keloids.

Cryotherapy should be delivered properly and repeated as many times as needed. Liquid nitrogen is best applied to the keloid tissue using a properly sized hand-held applicator; such as a large cotton swab. The process should be repeated until the entire mass of keloid is frozen to the level of normal ear tissue. Within a few hours, the treated tissue becomes edematous and swollen and often forms a blister which often bursts and oozes serous fluid for several days. During this time frame, the treated keloid should be attended to as an open wound; thus, it is best covered with gauze and a loose dressing. Within the next several days, the treated tissue will become dehydrated and form a black-colored scab, which will remain in place for a few weeks. The scab will then gradually slough off. This process takes two to three weeks for very small keloids and up to six to eight weeks for larger keloids. In the author's experience, upon recovery from the first treatment, most keloids show 30-60\% reduction in mass. Cryotherapy should be repeated, often every four to eight weeks in the same fashion until the keloid mass is totally destroyed. Depending on the size of the primary keloid, this process takes four to eight months and results in total removal of the primary keloids in almost every patient. Pressure devices or intra-lesional steroids should be used in all patients who continue to have a keloid remnant within their ear tissue.

Pain control is critical during the application of cryotherapy as well as during the first 24 hours after treatment. Inadequate pain control will result in a lack of compliance and poor treatment outcome. All patients should be educated about the process, and prescribed proper pain control medications.

Furthermore, there is no need to perforate the body of keloid with a very large bore metallic cannula, and to run liquid nitrogen through the core of keloid ${ }^{14}$. There exist no data, and no evidence to support superiority of this invasive technique to standard, noninvasive contact cryotherapy.

Although we can successfully debulk and remove almost all primary ear keloids with cryotherapy, there is a clear need for follow up in all patients in order to detect and treat early recurrences. Repeat cryotherapy, intra-lesional steroid and/or intra-lesional chemotherapy should be considered in treating keloid recurrence. 

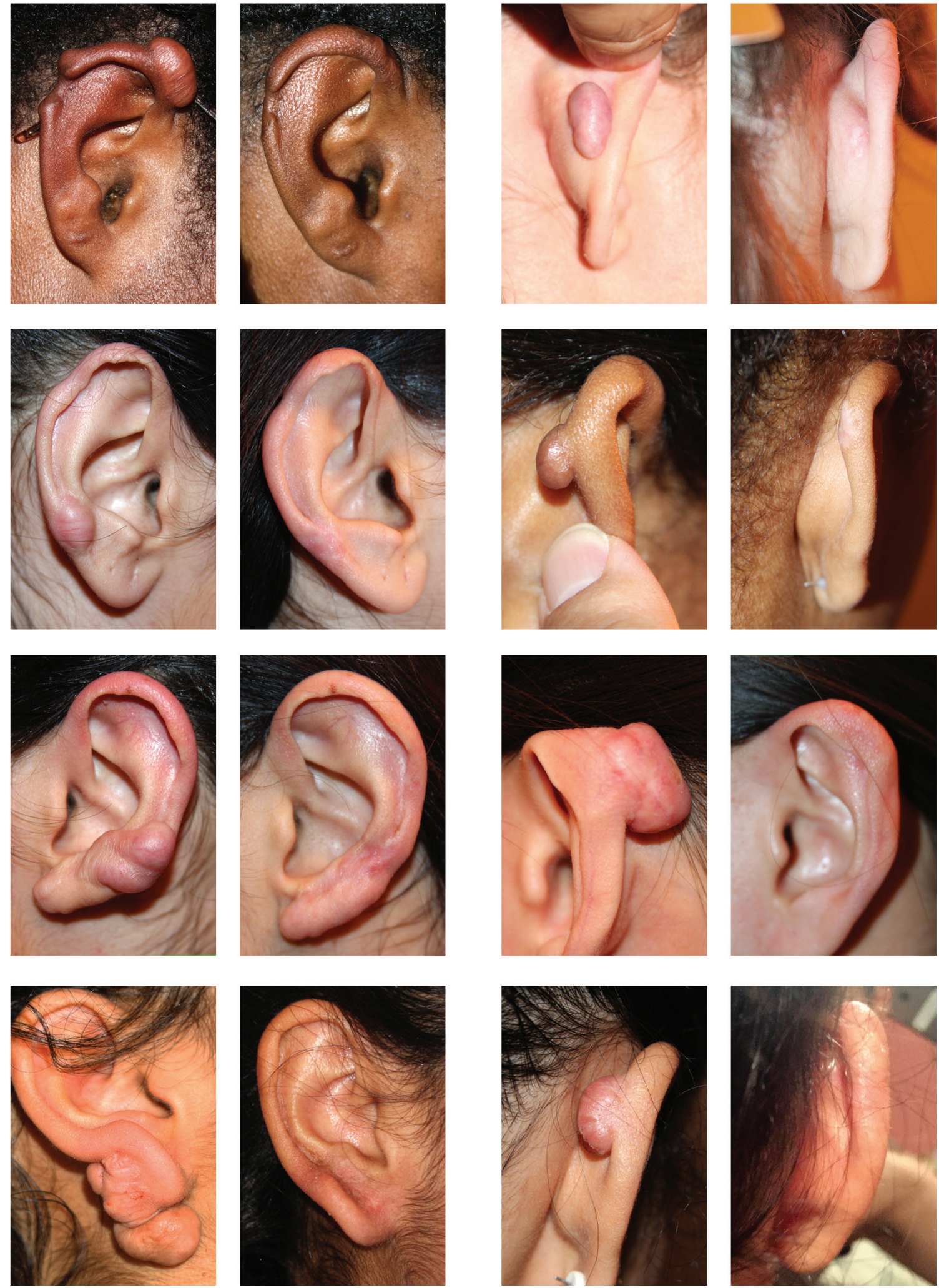

Figure 7. Successful keloid removal with contact cryotherapy for small primary and secondary (left column, bottom two cases) keloids. Notice the very minimal scarring at the site of cryotherapy. Most of these patients have enjoyed very durable and persistent results. 


\section{Primary Keloids}

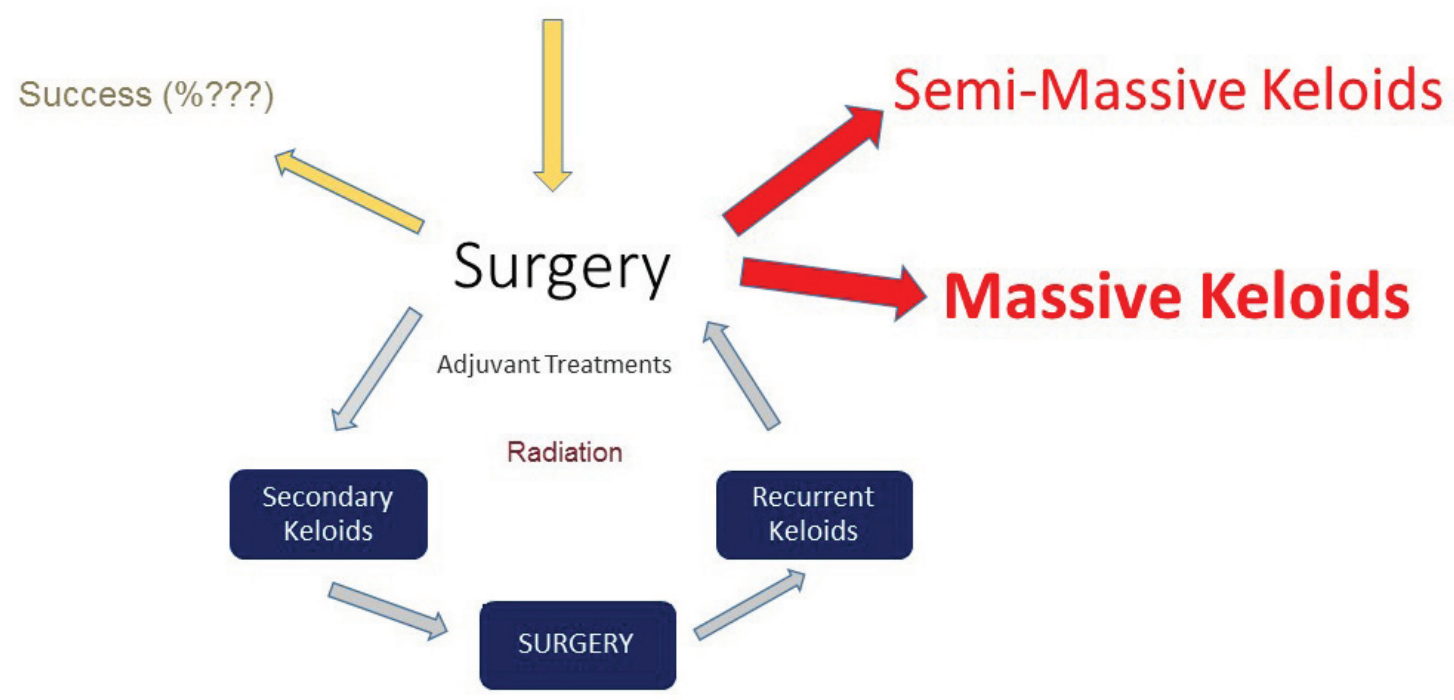

Figure 8. Vicious cycle of keloid removal surgery that results in the formation of semi-massive and massive in ear keloids.

\section{Conclusions}

The goal of treatment for keloid lesions, and ear keloids in particular, should not only focus on removal of the keloid tissue, but most importantly on two other very important principles:

\section{Prevention of damage to the ear tissue}

\section{Prevention of the recurrence of the keloid}

Performing surgery to remove primary ear keloids is inherently contrary to both of the above principles. Surgery, by its nature, induces new injury to the skin, and as shown in Figure 6, the surgical removal of a primary keloid frequently results in the loss of surrounding normal ear tissue. The loss of normal ear tissue, even in the absence of future keloid recurrence, will often result in an unacceptable aesthetic outcome. The worsening of ear keloids after surgical excision is caused by the triggering of the same dysregulated wound healing response, yet to a new dermal injury that is more extensive in nature than the injury from the ear piercing itself.

\section{Recommendations}

Topical contact cryotherapy should be the primary mode of treatment for all primary and secondary ear keloids. This approach will prevent the development of incurable secondary and, large, semi-massive and massive keloids and eliminate the need for hazardous adjuvant radiation therapy.

\section{Data availability}

All raw data relevant to the study are provided in tables above.

\section{Competing interests}

No competing interests were disclosed.

\section{Grant information}

The author(s) declared that no grants were involved in supporting this work.
1. Marneros AG, Norris JE, Olsen BR, et al:: Clinical genetics of familial keloids. Arch Dermatol. 2001; 137(11): 1429-34. PubMed Abstract | Publisher Full Text

2. Park TH, Park JH, Tirgan MH, et al:: Clinical implications of single- versus multiple-site keloid disorder: a retrospective study in an Asian population. Ann Plast Surg. 2015; 74(2): 248-51. PubMed Abstract | Publisher Full Text

3. Tirgan MH, Shutty CM, Park TH: Nine-month-old patient with bilateral earlobe keloids. Pediatrics. 2013; 131(1): e313-7. PubMed Abstract | Publisher Full Text

4. Al Aradi IK, Alawadhi SA, Alkhawaja FA, et al.: Earlobe keloids: a pilot study of the efficacy of keloidectomy with core fillet flap and adjuvant intralesional corticosteroids. Dermatol Surg. 2013; 39(10): 1514-9. PubMed Abstract | Publisher Full Text

5. Tanaydin V, Beugels J, Piatkowski A, et al.: Efficacy of custom-made pressure clips for ear keloid treatment after surgical excision. J Plast Reconstr Aesthet 
Surg. 2016; 69(1): 115-21.

PubMed Abstract | Publisher Full Text

6. van Leeuwen MC, Stokmans SC, Bulstra AE, et al:: Surgical Excision with Adjuvant Irradiation for Treatment of Keloid Scars: A Systematic Review. Plast Reconstr Surg Glob Open. 2015; 3(7): e440.

PubMed Abstract | Publisher Full Text | Free Full Text

7. Tirgan MH: Neck keloids: evaluation of risk factors and recommendation for keloid staging system [version 2; referees: 1 approved, 1 approved with reservations]. F1000Research. 2016; 5: 1528.

Publisher Full Text

8. Bijlard E, Kouwenberg CA, Timman R, et al.: Burden of Keloid Disease: A Crosssectional Health-related Quality of Life Assessment. Acta Derm Venereol. 2016. PubMed Abstract | Publisher Full Text

9. van Leeuwen MC, Stokmans SC, Bulstra AE, et al:: Surgical Excision with Adjuvant Irradiation for Treatment of Keloid Scars: A Systematic Review. Plast Reconstr Surg Glob Open. 2015; 3(7): e440.

PubMed Abstract | Publisher Full Text | Free Full Text
10. Zouboulis CC, Orfanos CE: [Cryosurgical treatment of hypertrophic scars and keloids]. Hautarzt. 1990; 41(12): 683-8. PubMed Abstract

11. Barara M, Mendiratta V, Chander R: Cryotherapy in treatment of keloids: evaluation of factors affecting treatment outcome. $J$ Cutan Aesthet Surg. 2012; 5(3): 185-9.

PubMed Abstract | Publisher Full Text | Free Full Text

12. Rusciani L, Paradisi A, Alfano $\mathrm{C}$, et al.: Cryotherapy in the treatment of keloids. J Drugs Dermatol. 2006; 5(7): 591-5. PubMed Abstract

13. Fikrle T, Pizinger K: Cryosurgery in the treatment of earlobe keloids: report of seven cases. Dermatol Surg. 2005; 31(12): 1728-31.

PubMed Abstract | Publisher Full Text

14. van Leeuwen MC, Bulstra AE, Ket JC, et al:: Intralesional Cryotherapy for the Treatment of Keloid Scars: Evaluating Effectiveness. Plast Reconstr Surg Glob Open. 2015; 3(6): e437.

PubMed Abstract | Publisher Full Text | Free Full Text 


\title{
Open Peer Review
}

\section{Current Peer Review Status: ? ?}

\section{Version 1}

Reviewer Report 09 January 2017

https://doi.org/10.5256/f1000research.10237.r19062

(C) 2017 McMichael A. This is an open access peer review report distributed under the terms of the Creative Commons Attribution License, which permits unrestricted use, distribution, and reproduction in any medium, provided the original work is properly cited.

\author{
Amy J. McMichael \\ Department of Dermatology, Wake Forest School of Medicine, Winston-Salem, NC, USA
}

This is a good accounting of keloids with many cases for discussion. The placement of new data in the discussion section is a bit off-putting for the reader. I would recommend placing all the charts in the Results section rather than having them in the Methods Section. Also, there needs to be more than just the grouping of keloids as presented. Basically, this is a list of keloids. There needs to be some correlation drawn or statistics to note associations rather than just descriptive stats. This is a great start, but just needs more to really give the reader information that is useful. I recommend not putting new data in the discussion and conclusion and moving this to the results.

The analysis used on the cases should be included in the methods section. The discussion should focus on the natural history of all the things that are discussed in the results sections.

Competing Interests: No competing interests were disclosed.

I confirm that I have read this submission and believe that I have an appropriate level of expertise to confirm that it is of an acceptable scientific standard, however I have significant reservations, as outlined above.

Reviewer Report 15 November 2016

https://doi.org/10.5256/f1000research.10237.r17447

(C) 2016 Sidbury R. This is an open access peer review report distributed under the terms of the Creative Commons Attribution License, which permits unrestricted use, distribution, and reproduction in any medium, provided the original work is properly cited.

\section{Robert Sidbury}

Seattle Children's Hospital, University of Washington School of Medicine, Seattle, WA, USA 
Overall this is a nice review. There are certain small additions I would make (e.g. a line somewhere capturing the idea that keloids can be seen in certain syndromes disproportionately such as Rubinstein-Taybi syndrome). This might reasonably be placed in the abstract (e.g. KD is an inherited wound healing ailment, frequently seen among Africans/African Americans, Asians, and in some genetic disorders such as Rubinstein Taybi syndrome). A notation like this in the introduction would also make more complete.

The aforementioned criticism pales in comparison with my overarching concern that this article has more of an agenda than just information dissemination. The agenda is that surgery is bad for ear keloids and the author does not shy away from this opinion. My concern is not that he expresses this opinion, even advocates for it to a certain extent if he believes it to be true, but the lengths he takes this, and the way he uses his "data" asymmetrically to make this point gives me pause.

First, what about the point itself? Is it valid? Is surgery bad for keloids? Yes, surgery is an injury to the skin which can itself promote keloid formation, indeed so much so that our surgeons will not operate to remove or debulk keloids in certain areas (eg neck, trunk). However, they do believe and I have shared plenty of patients to validate that ear keloids can be effectively removed in a sustainable, cosmetically acceptable way without necessarily (and in fact rarely) resorting to radiation therapy adjunctively. This sort of response is well-documented in the literature they just don't happen to be references this author cites:

Triamcinolone after surgery as effective as radiation therapy (and both can be effective) at preventing recurrence ${ }^{1}$

Pressure clips after surgery can prevent recurrence (this is technique used by my colleagues in Plastic Surgery to good effect) ${ }^{2}$

There are countless other references of success using surgery with acceptable risk-benefit profiles.

Second, where do I believe the author goes beyond simply stating his opinion, backed up by his data, that surgery can lead to recurrence and poor outcome?

First paragraph page 3, final sentence, "...unfortunately, ear keloids will continue...". This is stated as if it is ALWAYS the case and it simply is not.

Why did he not include post-otoplasty patients in study?

p 8 Results: Don't have experience with their own surgical successes because none of these patients have that modality ("do not offer surgery for treatment of keloids"). Therefore the only patients they see are surgical failures.

p 8 under Secondary Ear Keloids: "Cognizant of the fact that there are patients whose keloids do not recur after surgery..." and then there is no balance in what follows. This context that author describes speaks to the need for an appropriate and careful risk-benefit discussion but not necessarily not offering surgery at all when there are many reasons why it is sometimes the right choice. What if the keloid itself is life altering? What if they do not have time to return for repeated liquid nitrogen over the course of a year? With the attendant blistering and healing phases played out with each treatment? And the cost? 
p 10 paragraph 2: "1\% risk of causing massive or semi-massive ear keloids is unacceptable" all depends on patient and context.

Figure 6: "after" shots should be paired with "before" shots; I can imagine at least some of these outcomes potentially preferable to keloid it replaced but can't know without seeing images.

p 10: Need for a paradigm paragraph \# 1. Stop all surgery, cryo for all...this just isn't practical or medically justifiable.

p 10 cryotherapy paragraph: This just isn't possible for all patients. Problems include time, $\$$, quality of life during treatment, incomplete response because not all patients respond to cryo; post inflammatory pigment alteration secondary to cryo especially in darker skinned patients which this author does not mention at all.

So, in summary, this is simply too one-sided and agenda driven to be an appropriate publication in my opinion. Could it be modified? Sure. Present cryotherapy and other options alongside surgery and feel free to opine but a more balanced presentation with updated references would be required for me to endorse.

\section{References}

1. Shin JY, Lee JW, Roh SG, Lee NH, et al.: A Comparison of the Effectiveness of Triamcinolone and Radiation Therapy for Ear Keloids after Surgical Excision: A Systematic Review and Meta-Analysis. Plast Reconstr Surg. 2016; 137 (6): 1718-25 PubMed Abstract | Publisher Full Text

2. Tanaydin V, Beugels J, Piatkowski A, Colla C, et al.: Efficacy of custom-made pressure clips for ear keloid treatment after surgical excision.J Plast Reconstr Aesthet Surg. 2016; 69 (1): 115-21 PubMed Abstract | Publisher Full Text

Competing Interests: No competing interests were disclosed.

\section{I confirm that I have read this submission and believe that I have an appropriate level of expertise to confirm that it is of an acceptable scientific standard, however I have significant reservations, as outlined above.}

Author Response 18 Nov 2016

Michael Tirgan, Keloid Research Foundation, New York, USA

Dear Dr. Sidsbury:

Thank you very much for taking the time to review and comment on my publication. Peer review plays an important role in publishing research material. I truly appreciate your detailed and thorough review and each and every comment you have made. I hereby address the points you have raised.

1. As for referencing to Rubinstein-Taybi Syndrome - This manuscript is focused on providing data about Massive Ear Keloids. It is by no means review of the disorder.

2. As for your comment about my point being that "surgery is bad for ear keloids" - I am 
personally convinced that to be the case. Keloid is a genetic disorder that involves much of the normal appearing skin. It is not limited to the area of a keloid growth, therefore surgery cannot cure it. There are numerous publications that have eloquently explained this fact. This conclusion is backed by data as presented in the manuscript. It is also backed by clinical observation of some physicians, and parents and relatives of keloid patients, who dissuade patients from undergoing surgery.

3. As for your comment "therefore the only patients they see are surgical failures" - this is simply not correct. Patients shown in Figure 5 are some of my patients who presented with very early stages of ear keloid and had chosen a non-surgical approach. As for breakdown of the study cohorts, there were 283 patients in the study. 31 patients had massive or semi-massive ear keloids. Among 181 patients with large keloids, only $73 \%$ had prior surgery and $27 \%$ rest of these patients never had surgery. Of the 71 patients in the "small ear keloid" majority had not undergone surgery. Altogether, more than a third of all patients did not have surgery.

4. As for your comment about this manuscript being "agenda driven" - I simply disagree with you. My conclusions are rather data driven. We - as physicians and as healers have the ethical and moral obligation of providing our patients with the best available treatment. The Declaration of Geneva of the World Medical Association binds us with the words, "The health of my patient will be my first consideration," and the International Code of Medical Ethics declares that, "A physician shall act in the patient's best interest when providing medical care.". It is the duty of the physician to promote and safeguard the health, well-being and rights of patients.

The Declaration of Geneva also states that "The primary purpose of medical research involving human subjects is to understand the causes, development and effects of diseases and improve preventive, diagnostic and therapeutic interventions (methods, procedures and treatments). Even the best proven interventions must be evaluated continually through research for their safety, effectiveness, efficiency and accessibility." Purpose of this study was to exactly do what the Declaration of Geneva was intended us to do. Data provided in the manuscript points to the shortcomings of surgery by way of causing massive and semi-massive keloids. Manuscript provides argument as to why this may be the case. All conclusions are driven by data.

5. As for your comments about surgery that "This sort of response is well-documented in the literature they just don't happen to be references this author cites", I would refer to the two references provided at the conclusion of your comments.

Shin et. al reported "The recurrence rate after surgical excision of an ear keloid in the triamcinolone group was estimated as 15.4 percent. The recurrence rate in the radiation therapy group was estimated as 14.0 percent."

Tanaydin et. al reported "Keloid scars did not recur in 70.5\% of treated patients". By doing the math, the recurrence rate was $29.5 \%$ among patients who used custom made pressure clips after surgery. 
There is no doubt that some patients develop massive and semi-massive keloids - the ones who fail to respond to the best surgical efforts - i.e. the $14-15 \%$ (one in six patients) reported by Shin and $29.5 \%$ (one in three) reported by Tanaydin.

I hope to see more publications about the incidence of massive and semi-massive ear keloids. As of this date, searching pubmed does not locate even one publication about incidence of massive ear keloids.

I do advocate cryotherapy as primary treatment of all bulky ear keloids. There are several references that lend support to the usage of cryotherapy for treatment of ear keloids. Cryotherapy, as a treatment modality for keloids is also mentioned in every textbook of dermatology and in every overview of keloids, however, hardly any dermatologist or plastic surgeon uses it.I wonder why? no billing codes for application of cryotherapy for treating keloids.

6. As for "not including post-otoplasty cases" - there were only 14 patients. I have written is separate manuscript about this cohort.

7. As for figure 6 - the point was to show less than ideal aesthetic outcome of ear keloid surgery.

8. As for paradigm shift to stop surgery - I think it can be done. Although surgery is a quick-fix and results in immediate removal of ear keloids, it does cause long term harm to many patients. To this date, we do not have a methodology to identify who will be the next patient at risk of developing a massive ear keloid after surgical removal of a small primary ear keloid. In my data set, the rate is close to $11 \%$. To know the exact risks and outcomes, we need establish a Keloid Surgery Registry, and register each and every keloid patient who undergoes surgery, and follow them for several years. In absence of such data, or data from a well-designed randomized trial, all we can do is to inform our patients of the potential risks of keloid surgery.

There are many circumstances - but most importantly when surgery is performed on a patient - that we have the duty to obtain "informed consent" and not just a "permission to operate". We also have the duty to advise our patients of the specific risks of the procedure. We do know that disclosure of the general risks that are associated with any surgical procedure is not adequate. We are obligated to disclose the risk of developing massive and semi-massive keloids to each and every patient who is to undergo keloid removal surgery. We are also obligated to discuss alternative procedures, or conservative nonsurgical approaches with our patients. Through informed consent process, we have the ethical and moral obligation of showing the images of massive and semi-massive ear keloid to their patients, and informing them that with keloid surgery, there is a risk of developing such lifechanging complications.

9. As for the cost, risks, rate of skin discoloration and other aspects of cryotherapy, only a well-designed randomized study to compare surgery to contact cryotherapy will be able to answer all these valid points. I hope that there will be enough interest to 
support and fund such a study.

10. Finally, I am of the view that we all should respect data, disease biology and the process of informed consent. I only wish to improve the outcome of our patients. I hope that through collaborations with physicians like yourself, we can join forces and tackle this very hard-to-treat disorder.

Thank you again for all your comments.

Michael H. Tirgan, MD

Competing Interests: No competing interests were disclosed.

The benefits of publishing with F1000Research:

- Your article is published within days, with no editorial bias

- You can publish traditional articles, null/negative results, case reports, data notes and more

- The peer review process is transparent and collaborative

- Your article is indexed in PubMed after passing peer review

- Dedicated customer support at every stage

For pre-submission enquiries, contact research@f1000.com 